\title{
CARPOLOGICAL INVESTIGATIONS ON SOME CIRSIUM (ASTERACEAE, CARDUOIDEAE) TAXA FROM NE ANATOLIA
}

\author{
M. Ozcan \\ Department of Forest Engineering, Faculty of Forestry, Artvin Coruh University \\ Artvin, Turkey; E-mail: melahat.ozcan@artvin.edu.tr
}

(Received: 05 January, 2018; Accepted: 18 April, 2019)

\begin{abstract}
In the present study, morphological and anatomical structures of cypsela - 12 Cirsium Miller (Carduoideae, Asteraceae) taxa belonging to two sections (sect. Cirsium and sect. Cephalonoplos) were investigated in detail with using stereomicroscope and light microscope. The taxa were evaluated comparatively in the aspect of carpological variations and their anatomies were presented in here for the first time. Morphological features including size, shape and colour of cypselae were examined. From anatomical observations, anatomical structures of pericarp, as well as the structure of testa were described. Cypselae colours differ from light brown to stramineous, sometimes with blackish striations. Their shapes change from oblong to oblanceolate, rarely obovate. The largest cypselae are present in C. echinus $(1.59 \pm 0.03 \mathrm{~mm} \times 4.68 \pm 0.07 \mathrm{~mm})$ and the smallest ones are found in C. subinerme $(1.20 \pm 0.02 \mathrm{~mm} \times 2.97 \pm 0.05 \mathrm{~mm})$. The pericarp is characterised by almost parenchymatous cells, while the testa is composed of lignified sclerenchymatous cell lines and crushed cells group. Secretory structure in testa bundle was evaluated. Results obtained from this study were compared with the present data in literature. Overall, morphological and anatomical characteristics of cypselae provide useful taxonomic markers in their classifications of the studied taxa of Cirsium but not distinctive for their sectional levels.
\end{abstract}

Key words: Asteraceae, carpology, Cirsium, cypsela, NE Anatolia

\section{INTRODUCTION}

Several different studies show that cypsela (achene) morphology is one of the constant characters and less affected by environmental factors (Sears 1922). Cypsela is determined as a fruit of Asteraceae and differed from cypsela by an additional layer over the pericarp (Barroso et al. 1999, Frangiote-Pallone and de Souza 2014, Marzinek et al. 2008, Spjut 1994). Cypsela anatomy have been widely used in elucidating taxonomic relationships in Asteraceae (Abid and Ali 2010, Abid and Qaiser 2009, Barthlott 1981, 1984, Blanca and Guardia 1997, Bruhl and Quinn 1990, Cron et al. 1993, Garg and Sharma 2007, Geng et al. 1994, Inceer et al. 2012, 2018, Lavialle 1912, Pandey and Kumari 2007, Singh and Pandey 1984, Stebbins 1953, Zhu et al. 2006), and the tribes Cynareae (Kadereit and Jeffrey 2007) and Cardueae (Dittrich 1977, 1985, Häffner 2000, Ozcan and Akinci 2019, Zarembo and Boyko 2008). 
Cirsium Miller is one of the largest genera in the subfamily Carduoideae (Asteraceae) and comprises almost 250-300 taxa (Smith 1977, Stevens 2001, Zomlefer 1994). This spiny genus has a Holarctic distribution extending from the northern Mediterranean area over Turkey to Caucasus (Häffner 2000). Some species are highly invasive weeds in field or cultivated areas. It has several diversity centres and Turkey is one of the gene centres. According to recent taxonomic studies, Cirsium is represented by 80 taxa, dividing into three sections (Cephalonoplos (Neck.) DC., Cirsium, Epitrachys DC.) and growing in very diverse altitudes from sea level to 3,000 $\mathrm{m}$ in Turkey (Davis and Parris 1975, Yildız 2012, Yıldiz et al. 2013, Duman et al. 2017).

Cirsium is closely related to the genus Centaurea L. and has complex taxonomy (Charadze 1998). Some Cirsium species also have morphological affinities with Carduus L., Cnicus L., and Centaurea. Some taxa display large morphological variations or have a high degree of overlapping morphological characters. Primary morphological characteristics leading to the complexity of the genus Cirsium are the structure of the florets and cypsela (achene), leaf shape and spiny habits (Davis and Parris 1975).

The species belonging to the genus Cirsium are used as weeds for animal breeding or cultivated as decorative plants (Charadze 1998). Several scientific examinations were carried out for this genus in the areas of vegetative anatomy (Ozcan et al. 2015), cytotaxonomy (Ozcan et al. 2008, 2011, Yüksel et al. 2013), chemotaxonomy (Boğa et al. 2014, Ozcan et al. 2016), and micromorphology (Köstekci and Arabac1 2011, Ozcan 2016, 2017) to obtain additional data for the phylogeny of complicated Cirsium taxa. However, cypselar anatomy in this genus has not received as much attention as it should have received.

In this context, the present investigation deals with detailed studies of cypsela morphologies and anatomies of all Cirsium taxa (12 taxa, 21 populations) distributed in NE Anatolia belonging to the two different sections. Special emphasis has been given to the compositions of pericarp and testa. The aim of this study is to obtain comparative information for the taxonomy of these taxa. This study presents for the first time a detailed account of cypsela anatomy of 12 Cirsium taxa from NE Anatolia. Data obtained from this study were evaluated to their potential value and in relation to the previous work in the genus Cirsium.

\section{MATERIAL AND METHODS}

\section{Plant collections}

A list of taxa (12 taxa, 21 populations) along with two sections examined was collected from natural populations of NE Anatolia in Turkey, and their names and voucher information are given in Table 1. Species identification 
and nomenclature follow Davis and Parris (1975) and Y1ldız (2012) and IPNI (International Plant Name Index). Herbarium materials were deposited in Artvin Coruh University Herbarium (ARTH).

\section{Morphological studies}

For each taxon, cypselae obtained from at least three different individuals were examined by using a stereomicroscope to ensure size, shape, colour and maturity. Fifteen to twenty cypselae were used for morphological analyses. They were photographed by using a stereomicroscope (Leica M60 with digital camera attachment DFC 295). Totally 21 populations were used for morphological calculations and measurements (Table 1).

\section{Anatomical examinations}

Mature cypselae were obtained from different plant capitula, and softened by boiling water for 3-4 days. Selected populations were used for anatomical preparations and several characters were evaluated (Tables 1-2). Cross sections made of middle of the fruits were prepared using cryostat. Sections were cut to a thickness of 15-20 $\mu \mathrm{m}$. All sections were stained in haematoxylin for about $15 \mathrm{~min}$ (Algan 1981). Glycerol solution was added on slides to obtain semi-permanent slides. Observations were made using Olympus BX53 Research microscope with digital camera attachment DP73 and the images of well stained sections captured digitally.

Five cross sections from at least three different samples were measured to assess the consistency of anatomical characters and to calculate the means and standard error among different cross sections using LM.

\section{Statistical analyses}

Data analysis was carried out on SPSS (version 19) software. Based on the data, Duncan's multiple-range test, one-way analysis of variance, was used in 10 selected quantitative values to identify the statistical importance of distinctions among the data. Differences between means were considered significant at $\mathrm{P}<0.05$ (Table 2).

\section{RESULTS}

Variations in cypsela morphological and anatomical structures were characterised and showed in Figures 1-4 as well as Tables 2-3. 


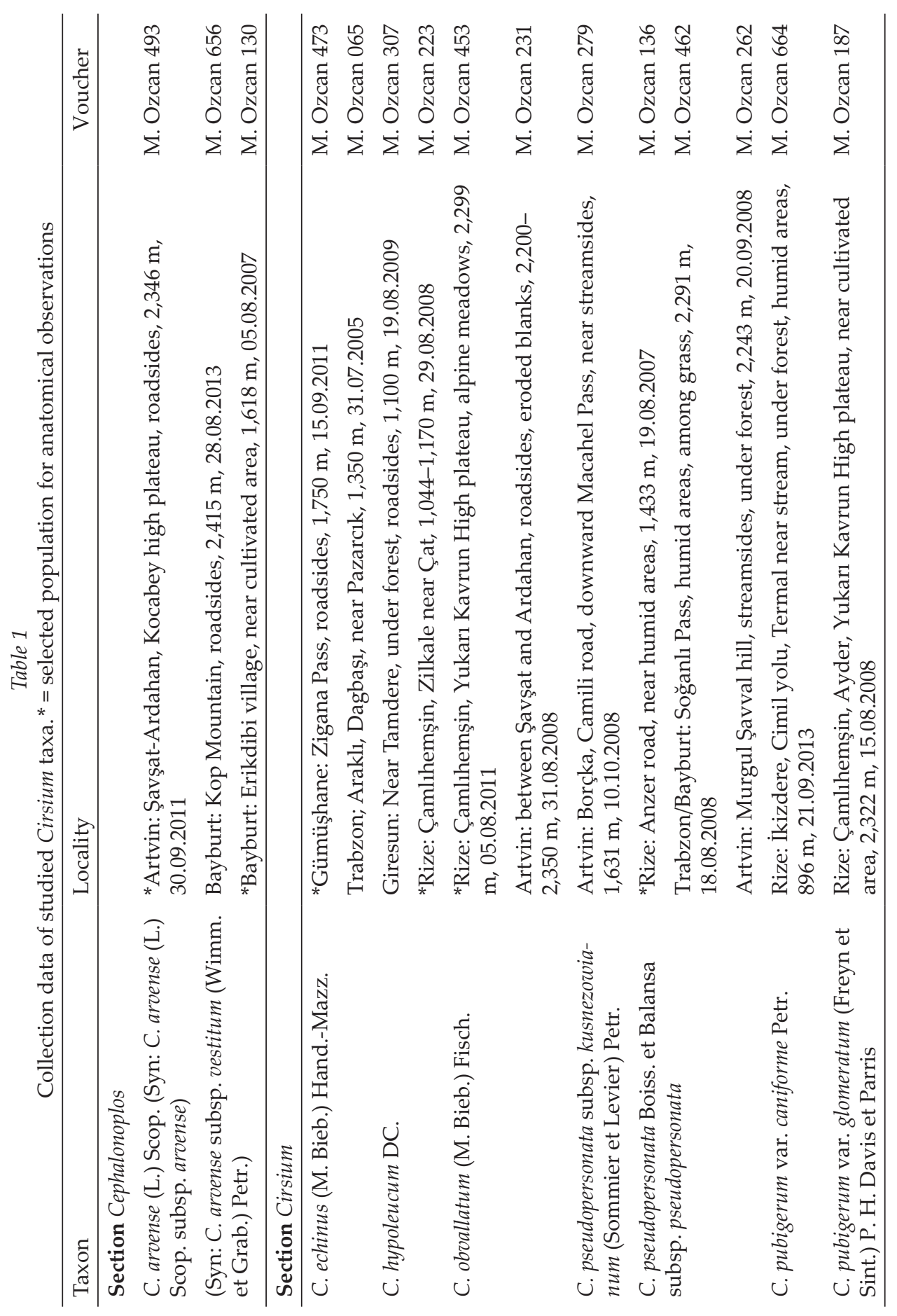




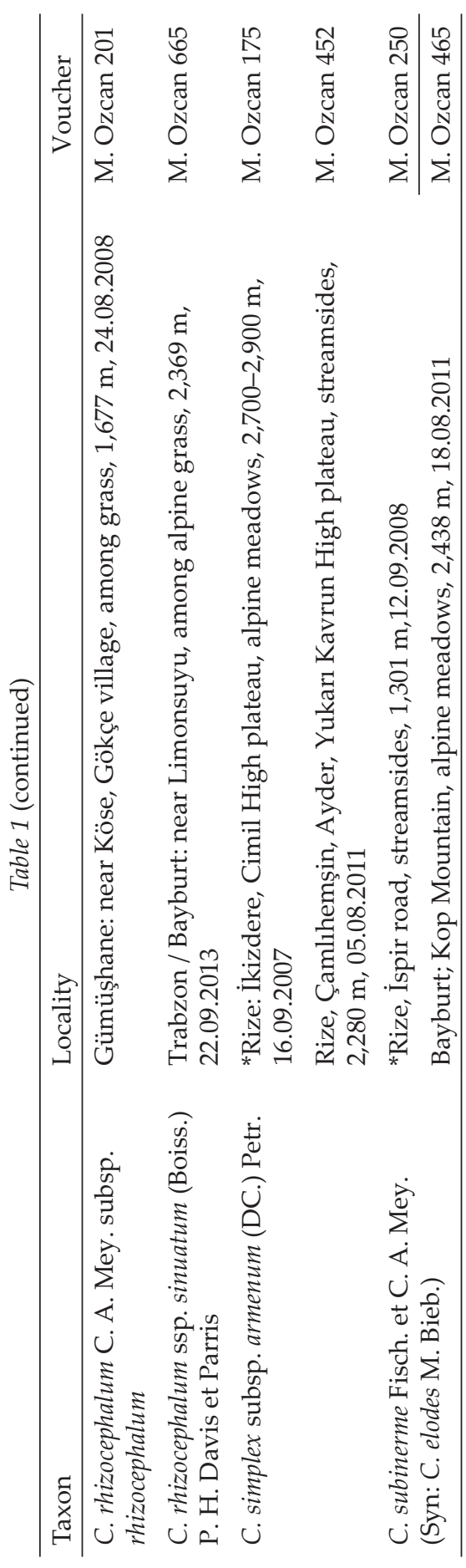

Cypsela morphology

Cypsela colours are light brown to stramineous, sometimes with black striations (Fig. 1). They are compressed slightly on both sides and mostly asymmetric or more or less symmetric (Cirsium hypoleucum, C. arvense) in outline, and has smooth surface and non-ribbed structure. Hilum is located at the base of cypsela. It has narrow base and acute apex. Carpopodium is undeveloped in all taxa. The mean lengths of cypselae range from 2.97 (C. subinerme) to $4.68 \mathrm{~mm}$ (C. echinus). Similarly, the mean width varies among 1.13 (C. arvense) and $1.68 \mathrm{~mm}$ (C. pubigerum var. glomeratum) (Table 2). The shapes of cypselae differ from oblong to oblanceolate, rarely obovate (two varieties of C. pubigerum) (Fig. 1). Colours vary from sordid-white to brown with blackish striations (Table 2). Pappus is plumose and caducous. The cypsela of $C$. echinus has the longest umbo in upper part as $0.62 \mu \mathrm{m}$, while C. pseudopersonata subsp. kusnezowianum has the smallest one as $0.20 \mu \mathrm{m}$ (Table 2).

\section{Cypsela anatomy}

Cypsela shapes in cross section are elliptic or ovate in outline (Figs 2-4). Their diameters parallel to cotyledons differ in maximum in Cirsium obvallatum $(1,856.53 \pm 46.58 \mu \mathrm{m})$ (Fig. 2D) as well as minimum in $C$. arvense $(1,227.09 \pm 33.69 \mu \mathrm{m})$ (Fig. 2M). Similarly, vertical diameters are observed 


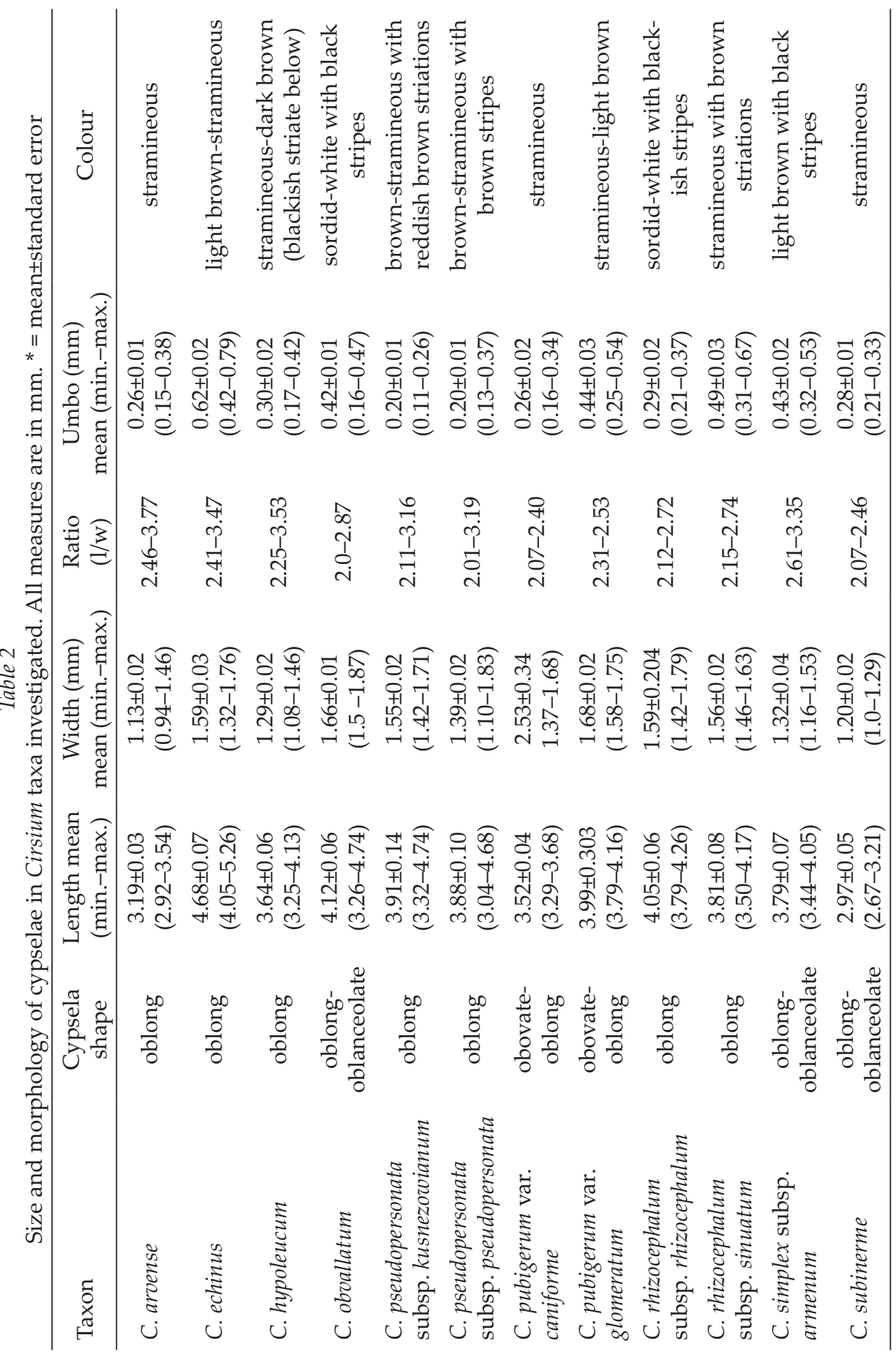


in maximum in $C$. obvallatum $(1,347.18 \pm 42.69 \mu \mathrm{m})$ as well as minimum in $C$. arvense $(895.79 \pm 14.77 \mu \mathrm{m})$ (Fig. $2 \mathrm{M}$, D, Table 3$)$.

Cypsela is composed of four different regions; pericarp, testa, endosperm and cotyledons. The mature pericarp is divided into two zones; exocarp and mesocarp, and shows variation in the structure (Figs 2-4).

A

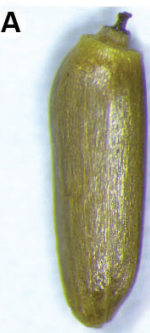

D

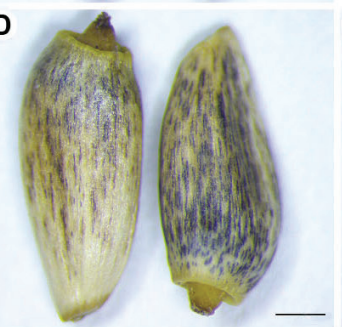

G
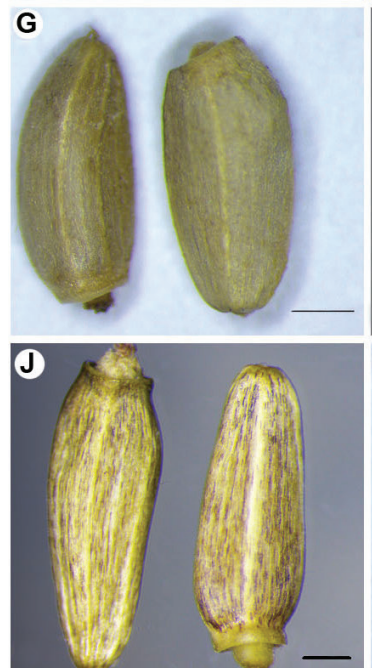

B

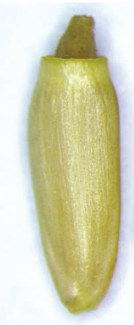

E
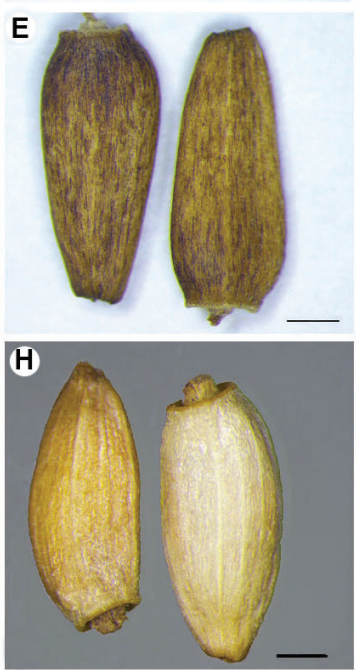

K

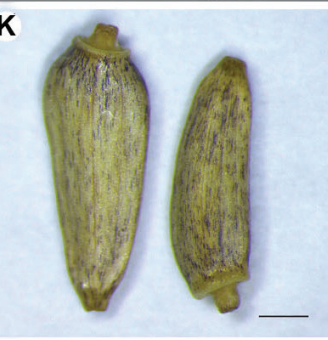

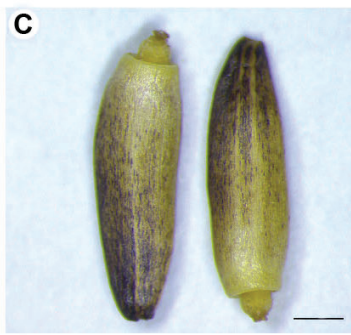

C
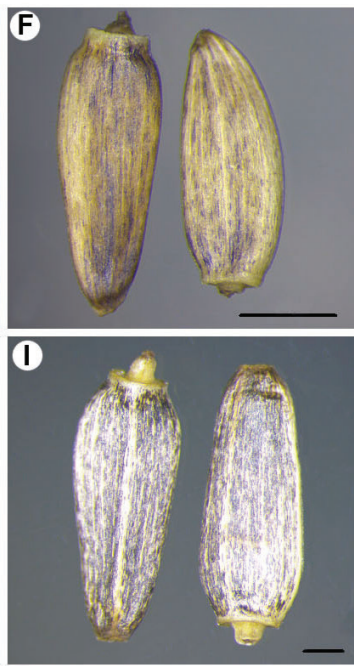

L

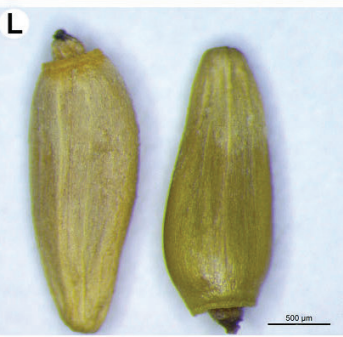

Fig. 1. Cypselae of the investigated taxa. $\mathrm{A}=\mathrm{C}$. arvense; $\mathrm{B}=\mathrm{C}$. echinus; $\mathrm{C}=\mathrm{C}$. hypoleucum; $\mathrm{D}=$ C. obvallatum; $\mathrm{E}=$ C. pseudopersonata subsp. kusnezowianum; $\mathrm{F}=$ C. pseudopersonata subsp. pseudopersonata; $\mathrm{G}=$ C. pubigerum var. caniforme; $\mathrm{H}=C$. pubigerum var. glomeratum; $\mathrm{I}=\mathrm{C}$. rhizocephalum subsp. rhizocephalum; $\mathrm{J}=\mathrm{C}$. rhizocephalum subsp. sinuatum; $\mathrm{K}=\mathrm{C}$. simplex subsp. armenum; $\mathrm{L}=\mathrm{C}$. subinerme 
Table $3 a$

Cypsela anatomical characteristics of investigated Cirsium taxa. ${ }^{*}=$ mean value \pm standard error

\begin{tabular}{|c|c|c|c|c|c|}
\hline \multirow[b]{2}{*}{ Taxon } & \multirow[b]{2}{*}{$\begin{array}{l}\text { Pericarp } \\
\text { thickness } \\
\quad(\mu \mathrm{m})\end{array}$} & \multicolumn{2}{|c|}{ Testa } & \multicolumn{2}{|c|}{ Vascular bundle } \\
\hline & & $\begin{array}{l}\text { Lignified } \\
\text { cells thick- } \\
\text { ness }(\mu \mathrm{m})\end{array}$ & $\begin{array}{l}\text { Crushed cell } \\
\text { thickness } \\
(\mu \mathrm{m})\end{array}$ & Length $(\mu \mathrm{m})$ & Width $(\mu \mathrm{m})$ \\
\hline \multirow{2}{*}{ C. arvense } & $23.80 \pm 1.77^{\mathrm{bc}}$ & $35.53 \pm 1.48^{\mathrm{a}-\mathrm{d}}$ & $13.09 \pm 0.48^{\mathrm{bc}}$ & $27.69 \pm 2.46^{\mathrm{a}-\mathrm{d}}$ & $48.12 \pm 5.09^{b-f}$ \\
\hline & $23.29 \pm 0.29^{\mathrm{bc}}$ & $36.79 \pm 0.97^{\text {a-e }}$ & $14.85 \pm 1.23^{\mathrm{bcd}}$ & $29.36 \pm 2.01^{\text {b-e }}$ & $43.42 \pm 3.82^{\mathrm{a}-\mathrm{d}}$ \\
\hline C. echinus & $52.98 \pm 6.96^{1}$ & $61.95 \pm 1.92^{\mathrm{kl}}$ & $13.40 \pm 0.62^{\mathrm{bcd}}$ & $43.83 \pm 4.12^{g}$ & $46.95 \pm 4.29^{\mathrm{a}-\mathrm{e}}$ \\
\hline C. hypoleucum & $15.97 \pm 1.64^{\mathrm{a}}$ & $46.71 \pm 0.80^{\mathrm{fgh}}$ & $17.40 \pm 1.19^{\text {cde }}$ & $29.49 \pm 1.33^{\text {b-e }}$ & $49.14 \pm 2.92^{\mathrm{b}-\mathrm{f}}$ \\
\hline C. obvallatum & $34.37 \pm 1.48^{\mathrm{ghi}}$ & $59.65 \pm 2.08^{\mathrm{k}}$ & $23.93 \pm 2.45^{\mathrm{fgh}}$ & $35.27 \pm 2.06^{\mathrm{ef}}$ & $62.05 \pm 4.39^{\text {fgh }}$ \\
\hline $\begin{array}{l}\text { C. pseudopersonata } \\
\text { subsp. kusnezowianum }\end{array}$ & $41.99 \pm 2.03^{j}$ & $65.23 \pm 4.34^{\mathrm{kl}}$ & $21.33 \pm 1.28^{\text {efg }}$ & $39.09 \pm 1.40^{\mathrm{fg}}$ & $59.83 \pm 1.99^{\mathrm{e}-\mathrm{h}}$ \\
\hline $\begin{array}{l}\text { C. pseudopersonata } \\
\text { subsp. pseudopersonata }\end{array}$ & $33.04 \pm 1.22^{\mathrm{f}-\mathrm{i}}$ & $51.17 \pm 1.06^{\text {hij }}$ & $17.97 \pm 1.04^{\text {cde }}$ & $33.52 \pm 0.84^{\text {def }}$ & $52.87 \pm 4.20^{\mathrm{d}-\mathrm{g}}$ \\
\hline $\begin{array}{l}\text { C. pubigerum var. } \\
\text { caniforme }\end{array}$ & $32.71 \pm 0.80^{\mathrm{e}-\mathrm{i}}$ & $59.59 \pm 1.05^{\mathrm{j}^{\mathrm{k}}}$ & $18.47 \pm 0.65^{\mathrm{de}}$ & $42.82 \pm 1.85^{g}$ & $58.78 \pm 8.05^{\mathrm{e}-\mathrm{h}}$ \\
\hline $\begin{array}{l}\text { C. pubigerum var. } \\
\text { glomeratum }\end{array}$ & $36.31 \pm 2.33^{\text {hij }}$ & $61.51 \pm 0.88^{\mathrm{jik}}$ & $33.74 \pm 4.33^{\mathrm{kl}}$ & $36.44 \pm 0.69^{\text {ef }}$ & $43.28 \pm 1.85^{a-d}$ \\
\hline $\begin{array}{l}\text { C. rhizocephalum } \\
\text { subsp. rhizocephalum }\end{array}$ & $42.51 \pm 2.14^{\mathrm{bc}}$ & $44.48 \pm 2.28^{\mathrm{ab}}$ & $20.59 \pm 0.75^{\mathrm{bcd}}$ & $29.39 \pm 2.55^{a b}$ & $44.16 \pm 2.46^{\mathrm{abc}}$ \\
\hline $\begin{array}{l}\text { C. rhizocephalum } \\
\text { subsp. sinuatum }\end{array}$ & $33.40 \pm 1.59^{\mathrm{jk}}$ & $44.01 \pm 1.13^{\mathrm{d}-\mathrm{h}}$ & $18.18 \pm 1.04^{\mathrm{efg}}$ & $32.86 \pm 0.69^{\mathrm{b}-\mathrm{e}}$ & $36.98 \pm 2.28^{a-d}$ \\
\hline $\begin{array}{l}\text { C. simplex subsp. } \\
\text { armenum }\end{array}$ & $23.17 \pm 0.94^{\text {ghi }}$ & $30.05 \pm 0.82^{\mathrm{d}-\mathrm{h}}$ & $13.72 \pm 0.83^{\text {cde }}$ & $25.72 \pm 1.99^{\mathrm{c}-\mathrm{f}}$ & $38.81 \pm 1.78^{\mathrm{ab}}$ \\
\hline C. subinerme & $22.94 \pm 0.95^{\mathrm{bc}}$ & $39.10 \pm 0.57^{\mathrm{b}-\mathrm{f}}$ & $11.90 \pm 0.35^{\mathrm{ab}}$ & $25.15 \pm 1.41^{\mathrm{ab}}$ & $33.62 \pm 3.62^{\mathrm{a}}$ \\
\hline
\end{tabular}

Epidermal cells forming the exocarp of the pericarp are uniseriate, thick walled rectangular to oval and the mesocarp consists of isodiametric parenchymatous cells. Differently from others, Cirsium echinus has slightly longitudinally elongated epidermal cells (Fig. 2H, I). The thickest pericarp is found in C. rhizocephalum subsp. rhizocephalum $(42.51 \pm 2.14 \mu \mathrm{m})$ (Fig. $4 \mathrm{~A}-\mathrm{C})$, while the thinnest one is observed in C. hypoleucum $(15.97 \pm 1.64 \mu \mathrm{m})$ (Fig. 2J-L). Four carpel bundle traces underlaid by a layer of parenchymatous cells (in the pericarp) and two testa bundles placed in opposite sides and between lignified cells and crushed cell groups are present. The testa body consists of two differentiated cell types, other zone with a single row longitudinally elongated, lignified cells (notable thickening and swelling on their radial walls) and inner zone with crushed parenchymatous cell group (inner zone). Lignified cell layer covers most of the testa. The highest and the smallest values of this layer are detected in C. pseudopersonata subsp. kusnezowianum $(65.23 \pm 4.34 \mu \mathrm{m})$ and C. simplex subsp. armenum $(30.05 \pm 0.82 \mu \mathrm{m})$, respectively. In the testa bundles 
Table $3 b$

Cypsela anatomical characteristics of investigated Cirsium taxa. ${ }^{*}=$ mean value \pm standard error

\begin{tabular}{|c|c|c|c|c|c|}
\hline \multirow[b]{2}{*}{ Taxon } & \multirow{2}{*}{$\begin{array}{l}\text { Endosperm } \\
\text { thickness } \\
(\mu \mathrm{m})\end{array}$} & \multicolumn{2}{|c|}{ Epidermal cell } & \multicolumn{2}{|c|}{ Cypsela diameter } \\
\hline & & Length $(\mu \mathrm{m})$ & Width $(\mu \mathrm{m})$ & $\begin{array}{c}\text { Parallel to coty- } \\
\text { ledons }(\mu \mathrm{m})\end{array}$ & $\begin{array}{c}\text { Vertical to coty- } \\
\text { ledons }(\mu \mathrm{m})\end{array}$ \\
\hline \multirow{2}{*}{ C. arvense } & $09.60 \pm 0.54^{e-j}$ & $05.83 \pm 0.22^{\mathrm{b}-\mathrm{f}}$ & $07.62 \pm 0.43^{\mathrm{b}-\mathrm{i}}$ & $1263.95 \pm 41.29^{a}$ & $992.78 \pm 51.43^{\mathrm{ab}}$ \\
\hline & $09.76 \pm 0.48^{f-j}$ & $04.74 \pm 0.38^{\mathrm{abc}}$ & $6.93 \pm 0.39^{\mathrm{a}-\mathrm{e}}$ & $1227.09 \pm 33.69^{a}$ & $895.79 \pm 14.77^{a}$ \\
\hline C.echinus & $07.35 \pm 0.25^{\mathrm{a}-\mathrm{d}}$ & $16.33 \pm 0.92^{p}$ & $11.42 \pm 0.27^{\text {no }}$ & $1712.32 \pm 15.17^{\mathrm{de}}$ & $1203.29 \pm 14.23^{\text {cde }}$ \\
\hline C. hypoleucum & $09.42 \pm 0.53^{\mathrm{d}-\mathrm{i}}$ & $07.43 \pm 0.52^{\mathrm{f}-\mathrm{j}}$ & $08.78 \pm 0.32^{\mathrm{e}-\mathrm{k}}$ & $1475.29 \pm 28.53^{\mathrm{bc}}$ & $1044.47 \pm 55.89 \mathrm{abc}$ \\
\hline C. obvallatum & $13.05 \pm 1.84^{1}$ & $10.14 \pm 0.61^{\mathrm{mn}}$ & $09.39 \pm 0.65^{\mathrm{i}-\mathrm{m}}$ & $1856.53 \pm 46.58^{e}$ & $1347.18 \pm 42.69^{\text {ef }}$ \\
\hline $\begin{array}{l}\text { C. pseudoper- } \\
\text { sonata subsp. } \\
\text { kusnezowianum }\end{array}$ & $11.58 \pm 1.09^{\mathrm{jkl}}$ & $11.51 \pm 0.42^{\text {no }}$ & $11.52 \pm 0.94^{\text {no }}$ & $1817.74 \pm 14.94^{\mathrm{de}}$ & $1267.85 \pm 23.45^{\text {def }}$ \\
\hline $\begin{array}{l}\text { C. pseudoper- } \\
\text { sonata subsp. } \\
\text { pseudopersonata }\end{array}$ & $06.94 \pm 0.21^{\mathrm{abc}}$ & $09.93 \pm 0.36^{\mathrm{Im}}$ & $10.75 \pm 0.33^{\mathrm{k}-\mathrm{n}}$ & $1623.51 \pm 33.37^{\mathrm{cd}}$ & $1102.89 \pm 12.55^{\mathrm{bcd}}$ \\
\hline $\begin{array}{l}\text { C. pubigerum } \\
\text { var. caniforme }\end{array}$ & $12.75 \pm 0.70^{1}$ & $11.86 \pm 0.45^{\circ}$ & $12.05 \pm 0.31^{\mathrm{op}}$ & $1795.42 \pm 33.54^{\mathrm{de}}$ & $1249.82 \pm 36.63^{\text {def }}$ \\
\hline $\begin{array}{l}\text { C. pubigerum } \\
\text { var. glomeratum }\end{array}$ & $05.80 \pm 0.31^{\mathrm{a}}$ & $09.62 \pm 0.35^{\mathrm{klm}}$ & $13.85 \pm 0.39 p$ & $1626.41 \pm 81.00^{\mathrm{cd}}$ & $991.73 \pm 34.96^{\mathrm{ab}}$ \\
\hline $\begin{array}{l}\text { C. rhizocephalum } \\
\text { subsp. rhizo- } \\
\text { cephalum }\end{array}$ & $08.72 \pm 0.66^{\mathrm{ab}}$ & $08.16 \pm 0.68^{\mathrm{c}-\mathrm{g}}$ & $09.44 \pm 0.52^{\mathrm{mno}}$ & $1797.70 \pm 23.60^{\mathrm{bc}}$ & $1136.16 \pm 21.40^{\mathrm{b}}$ \\
\hline $\begin{array}{l}\text { C. rhizocephalum } \\
\text { subsp. sinuatum }\end{array}$ & $09.13 \pm 0.46^{\mathrm{b}-\mathrm{g}}$ & $06.49 \pm 0.24^{\mathrm{h}-\mathrm{k}}$ & $10.93 \pm 0.72^{\mathrm{i}-\mathrm{m}}$ & $1664.37 \pm 59.19^{\text {de }}$ & $1306.56 \pm 42.49^{\mathrm{bcd}}$ \\
\hline $\begin{array}{l}\text { C. simplex subsp. } \\
\text { armenum }\end{array}$ & $06.59 \pm 0.24^{\mathrm{d}-\mathrm{h}}$ & $06.20 \pm 0.16^{\mathrm{d}-\mathrm{h}}$ & $11.31 \pm 0.41^{1-\mathrm{o}}$ & $1467.54 \pm 20.72^{\text {cde }}$ & $910.87 \pm 14.59^{e f}$ \\
\hline C. subinerme & $07.68 \pm 0.27^{\mathrm{a}-\mathrm{f}}$ & $07.10 \pm 0.63^{e-j}$ & $08.13 \pm 0.38^{d-j}$ & $1394.25 \pm 54.18^{\mathrm{ab}}$ & $982.72 \pm 48.90^{\mathrm{ab}}$ \\
\hline
\end{tabular}

of $C$. hypoleucum, two subspecies of $C$. pseudopersonata and two varieties of $C$. pubigerum, wide gaps were observed, differently from the others (Figs 2J, L, 3A, D-F, G, H, 4A).

A subjacent layer of the testa is endosperm or only remnants composed of one layer of elongated and thin-walled parenchymatous cells. The two cotyledons occupy a large region of in cypsela interior and they are oriented in anterior-posteriorly (Figs 2-4).

\section{DISCUSSION}

The genus Cirsium is widespread in the northern hemisphere and also mountains of southern Europe and in the Caucasus from sea level to high altitudes in the mountains. In this study, 12 Cirsium taxa from the two sec- 
tions and distributed in NE Anatolia were evaluated from morphological and anatomical aspects by stereomicroscope and light microscope. All anatomical data were detailed and compared for the first time.
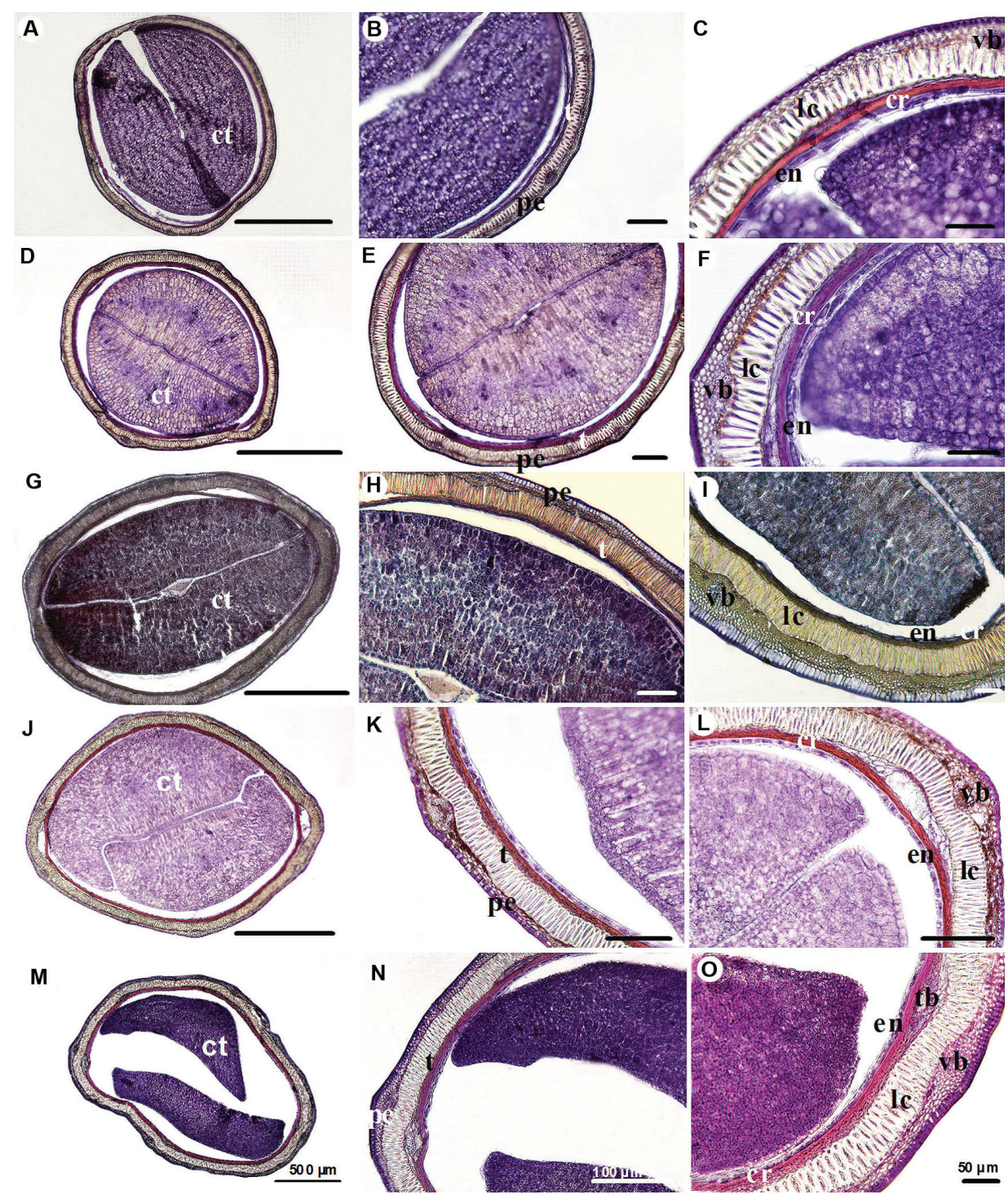

Fig. 2. Transverse sections of cypselae. $\mathrm{A}-\mathrm{F}=\mathrm{C}$. arvense; $\mathrm{G}-\mathrm{I}=\mathrm{C}$. echinus; $\mathrm{J}-\mathrm{L}=\mathrm{C}$. hypoleucum; $\mathrm{M}-\mathrm{O}=$ C. obvallatum $(\mathrm{cr}=$ crushed cell, $\mathrm{ct}=$ cotyledon, $\mathrm{e}=$ epidermis, $\mathrm{en}=$ endosperm, $\mathrm{lc}=$ lignified cell, $\mathrm{pe}=$ pericarp $, \mathrm{t}=\mathrm{testa}, \mathrm{tb}=$ testa bundle, $\mathrm{vb}=$ vascular bundle $)$. Scale bars $($ left $)=500 \mu \mathrm{m},($ middle $)=100 \mu \mathrm{m},($ right $)=50 \mu \mathrm{m}$ 
Cypsela mean lengths of investigated taxa differ from $2.97 \mathrm{~mm}$ (C. subinerme) to $4.68 \mathrm{~mm}$ (C. echinus) (Table 2) in the two sections (sect. Cephalonoplos and sect. Cirsium). Like in the present investigated taxa, Köstekci and Arabacı (2011) previously reported the smallest cypsela for C. pubigerum var. glomeratum, while the biggest one was determined in C. echinus. The present results are in accordance with this previous report. On the other hand, Ozcan (2017) reported mean cypsela lengths in sect. Epitrachys have differed from $4.26 \mathrm{~mm}$ to $7.46 \mathrm{~mm}$. In the other words, it can be concluded that cypselae of sect. Cirsium taxa have smaller than those of sect. Epitrachys.
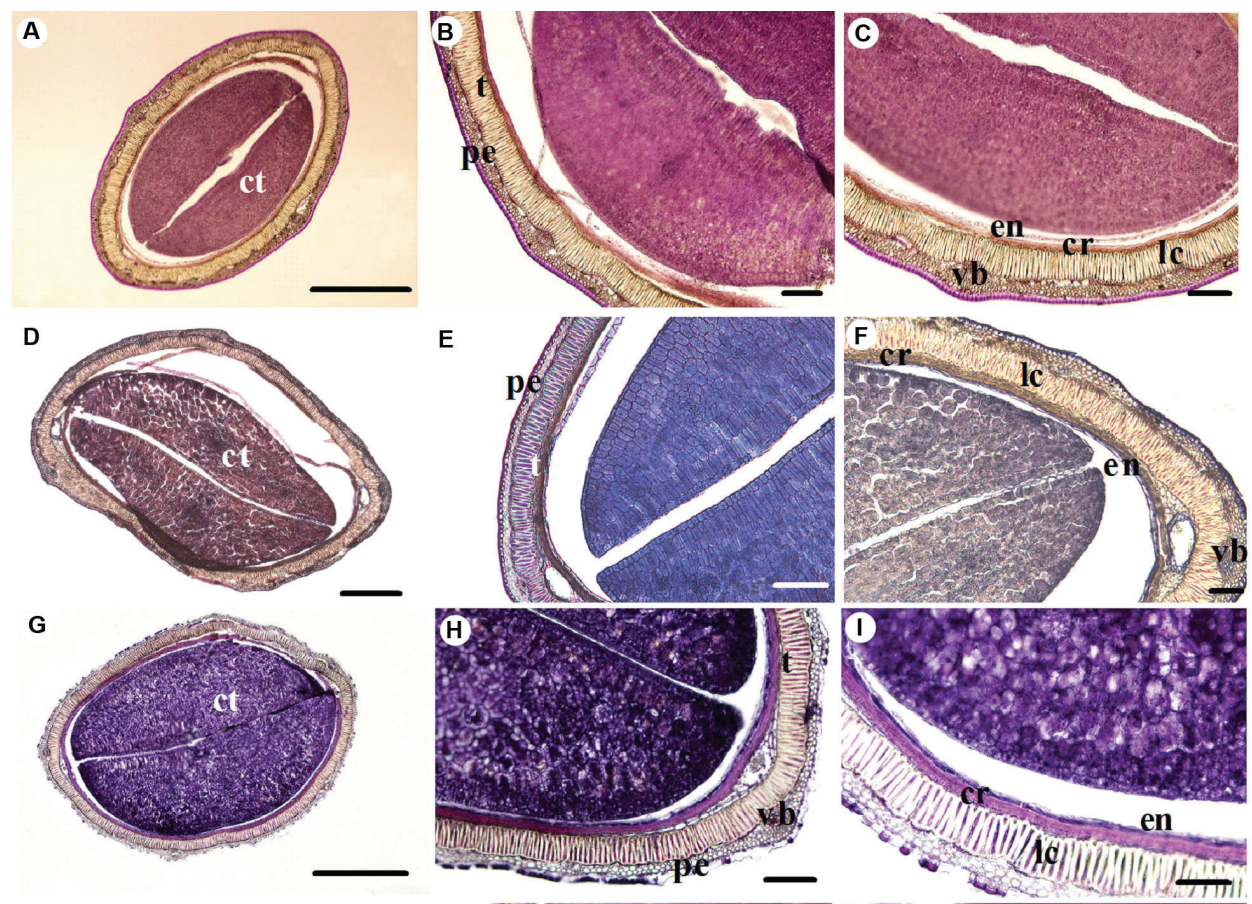

$\mathbf{J}$

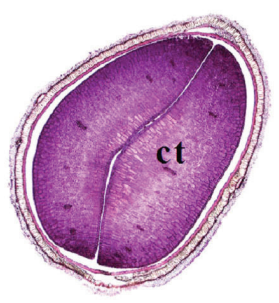

$\underline{500 \mu \mathrm{m}}$

K

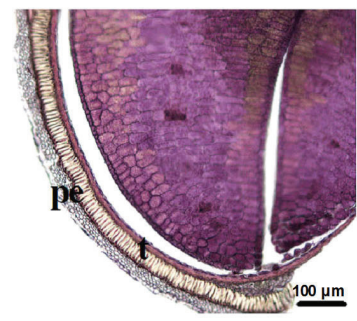

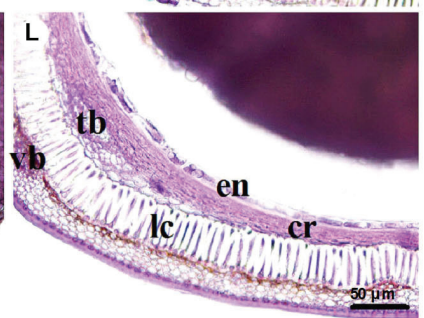

Fig. 3. Transverse sections of cypselae. A-C $=$ C. pseudopersonata subsp. kusnezowianum; $\mathrm{D}-\mathrm{F}=\mathrm{C}$. pseudopersonata subsp. pseudopersonata; $\mathrm{G}-\mathrm{I}=\mathrm{C}$. pubigerum var. caniforme; $\mathrm{J}-\mathrm{L}=\mathrm{C}$. pubigerum var. glomeratum. See Fig. 2 for abbreviations. Scale bars (left) $=500 \mu \mathrm{m}$, (middle)

$$
=100 \mu \mathrm{m},(\text { right })=50 \mu \mathrm{m}
$$


The cypsela surfaces of all investigated taxa in this study are smooth (not ribbed), oblong to oblanceolate rarely obovate, with compressed dorsal and ventral margins (Fig. 1). However, both ribbed and non-ribbed cypselae were previously reported in the family Asteraceae by Abid and Qaiser (2009).

The taxa examined here have uniseriate and thick walled epidermis, which included no trichomes on their surfaces. Shabestari et al. (2013) described in some Centaurea taxa with in their seed (cypsela) types with or without hairs on the surfaces. Sparsely long hairs were also reported in the cypselae of C. polyclada by Uysal et al. (2005). Andrés-Sánchez et al. (2015) referred to twin hairs in some species (e.g. Filago L.) in the family Asteraceae. However,
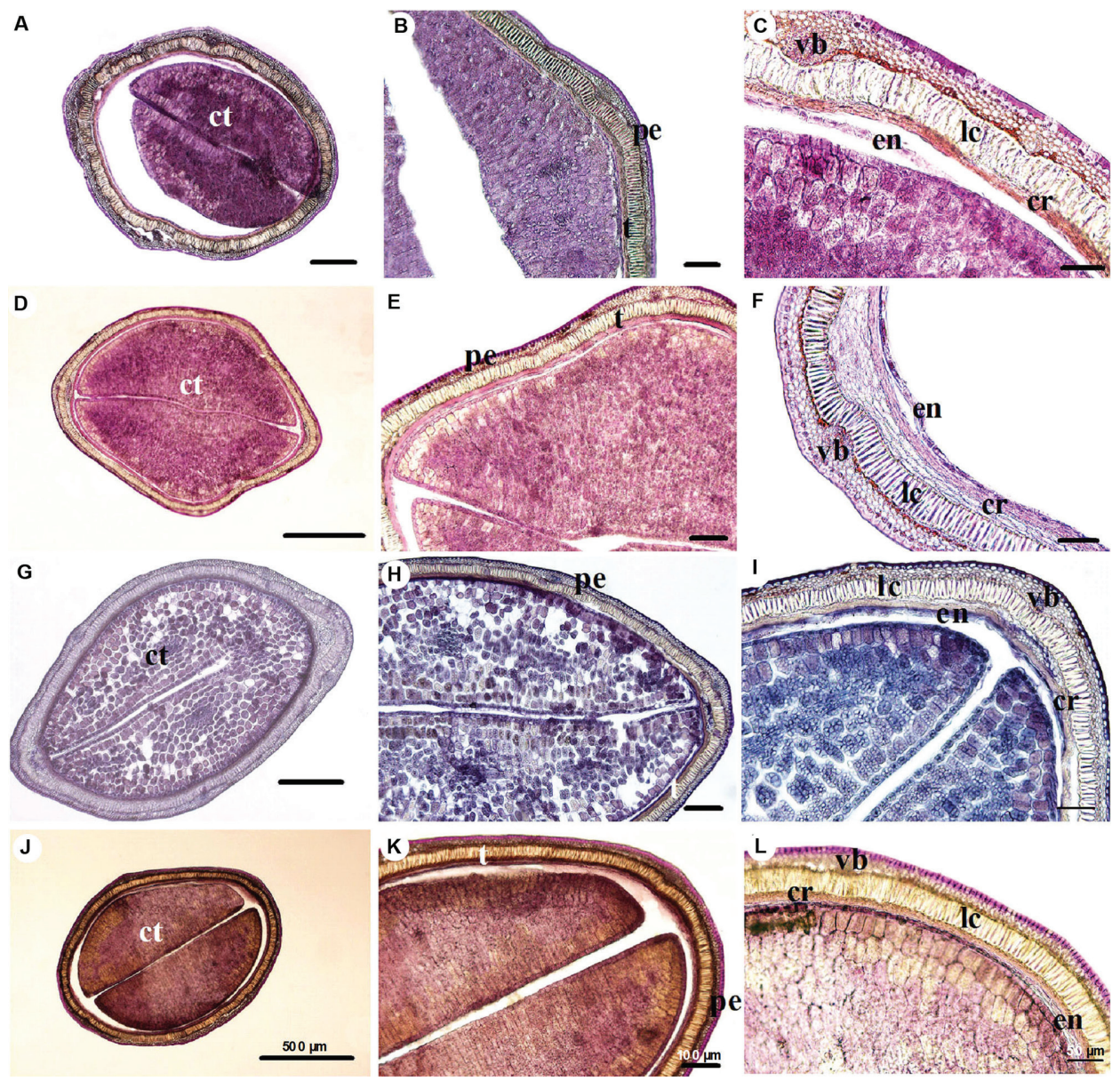

Fig. 4. Transverse sections of cypselae. $\mathrm{A}-\mathrm{C}=\mathrm{C}$. rhizocephalum subsp. rhizocephalum; $\mathrm{D}-\mathrm{F}=$ C. rhizocephalum subsp. sinuatum; $\mathrm{G}-\mathrm{I}=C$. simplex subsp. armenum; $\mathrm{J}-\mathrm{L}=\mathrm{C}$. subinerme. See

Fig. 2 for abbreviations. Scale bars $($ left $)=500 \mu \mathrm{m},($ middle $)=100 \mu \mathrm{m}$, (right) $=50 \mu \mathrm{m}$ 
Dittrich (1977) reported that twin hairs are never present on the cypsela surface in the subtribe Carduinae and Centaureinae. No hair type was observed in Cirsium taxa investigated in the present study (Fig. 1).

The anatomical structure of the cypselae in the sect. Epitrachys seems to be rather similar in outline. In the cypsela anatomies of taxa, five distinct parts can be determined; exocarp, mesocarp, testa, one layer endosperm and two large cotyledons. The pericarp zones were determined as exocarp and mesocarp. The exocarp is composed of uniformly thickened epidermal cells, parenchymatous cells and collenchymatous/sclerenchymatous cells, which around vascular bundles cover the entire mesocarp in all taxa. Sclerified epidermal cells have been previously reported in Carduus, Cirsium, Notobasis Cass., Picnomon Adans., Silybum Adans. and Trymnus Cass. by Häffner (2000). Thin epidermal cells and parenchymatous mesocarp have been reported in Rhaponticum Vaill., while both parenchymatous and sclerenchymatous tissues were determined in the species of Klasea Cass. and Serratula L. by Zarembo and Boyko (2008). Mukherjee (2001) also mentioned sclerenchymatous braces and parenchymatous cell layers in the mesocarpic zone in the tribe Senecioneae.

The testa of all taxa investigated exhibits well-developed, elongated, with radially stretched lignified cell and crushed cell layers near the single row endosperm. This type of pericarp and testa structure were previously reported by Häffner (2000) in some Carduinae and Centaureinae taxa, and by Zarembo and Boyko (2008) in some Cardueae genera, Rhaponticum, Klasea, Serratula and Synurus IIjin. Singh and Pandey (1984) reported an elongated and lignified testa structure in Centaurea moschata L. and in Silybum marianum (L.) Gaertn. A similar testa structure has been also determined in some species of Klasea and Serratula. The thick testa is characterised in Cirsium pseudopersonata subsp. kusnezowianum, and a comparatively thin one is observed in C. simplex subsp. armenum. On the other hand comparatively thick pericarp is present in C. echinus, whereas C. hypoleucum has the thinnest one, among the investigated taxa (Table 3). C. echinus has also slightly elongated epidermal cells like palisade parenchyma, differently from others. Crushed cell zone shows little variations among the investigated taxa. Four main vascular traces are found in the taxa. Four to five, sometimes six to seven vascular traces have been reported in the taxa of the tribe Cardueae by Häffner (2000).

Differently from other investigated ones, between lignified cells and crushed cell groups, in opposite directions of five taxa, large hollows were observed. They are probably secretory structures developed by lysigenous origin. Similarly, three different secretory structures have been determined in roots or rhizome by Fritz and Saukel (2011) as endodermal resin ducts (Cirsium vulgare), secretory ducts (C. arvense) and secretory cavities (Echinops sphaerocephalus) in some species of the tribe Cardueae. In addition, phytomelanin- 
coated cells were reported in roots of Centaurea jacea in that study. Detection of similar secretory structure, however, no phytomelanin-included cells were observed in the cypselae of investigated taxa in the present study.

A one-layer, elongated and thin-walled parenchymatous endosperm is observed in all taxa investigated. The thickest endosperm is determined in C. obvallatum, while the thinnest is shown in C. pubigerum var. glomeratum (Figs 2M-O, 3J-L, Table 3). Häffner (2000) reported that the appearance of endosperm does not differ significantly among the genera of the subtribe Carduinae. Grau and Hopf (1985) supposed that this structure probably provides an additional protection to the embryo.

Carpological features of some Cirsium taxa have been reported in two investigations till now. However, detailed investigations on morphological and anatomical data are still desirable. Three different reports were present in literature about cypsela of some Cirsium taxa; one is cypsela anatomy of Cirsium eriophorum (L.) Scop. (Häffner 2000), the second is carpology of C. aggregatum Ledeb. (Ozcan 2016) and the third is about micromorphology and anatomy of 17 Cirsium taxa (Ozcan 2017). In this study carpological characters were evaluated in detail. From anatomical points, all taxa investigated in the present study share similar patterns with C. eriophorum without sectional delimitations.

\section{CONCLUSION}

The data obtained from the present study demonstrate that the morphological and anatomical characters investigated are potentially informative. Especially, cypsela length, mesocarp and testa structure display diversity in Cirsium taxa. They are applicable for identification and can be used as a parameter to support species delimitation. Investigations of cypsela structures should therefore be included in future taxonomic and phylogenetic studies of the genus Cirsium, as well as in other genera within the tribe Cardueae.

Acknowledgement - The author would like to thank the research foundation of Artvin Coruh University (Project numbers: 2011.F15.02.16, 2016.F10.01.08) for financial support.

\section{REFERENCES}

Abid, R. and Ali, N. (2010): Cypsela morphology and its taxonomic significance for the tribe Senecioneae (Asteraceae) from Pakistan. - Pak. J. Bot. (SI) 42: 117-133.

Abid, R. and Qaiser, M. (2009): Taxonomic significance of the cypsela morphology in the tribe Anthemideae (Asteraceae) from Pakistan and Kashmir. - Pak. J. Bot. 41: 555-579. 
Algan, G. (1981): Bitkisel Dokular için Mikroteknik. - Fırat Universitesi, Fen Fakültesi Yayınları, Bot. No. 1. İstanbul. Matbaa Teknisyenleri Basımevi (in Turkish), 94 pp.

Andrés-Sánchez, S., Galbany-Casals, M., Bergmeier, E., Rico, E., Martínez-Ortega, M. M. (2015): Systematic significance and evolutionary dynamics of the achene twin hairs in Filago (Asteraceae, Gnaphalieae) and related genera: further evidence of morphological homoplasy. - Plant Syst. Evol. 301: 1653-1668. https://doi.org/10.1007/s00606014-1185-7

Barroso, G. M., Morim, M. P. A., Peixoto, L. and Ichaso, C. L. F. (1999): Frutos e Sementes: morfologia aplicada à sistemática de dicotiledôneas. - Editora UFV, Viçosa, 443 pp.

Barthlott, W. (1981): Epidermal and seed surface characters of plants: systematic applicability and some evolutionary aspects. - Nordic J. Bot. 1: 345-355. https://doi. org/10.1111/j.1756-1051.1981.tb00704.x

Barthlott, W. (1984): Microstructural features of seed surfaces. - In: Heywood, V. H. and Moore, D. M. (eds): Current concepts in plant taxonomy. Systematics Association, London, Academic Press, Special, vol. 25, pp. 95-105.

Blanca, C. C. and Guardia, C. D. (1997): Fruit morphology in Tragopogon L. (Compositae: Lactuceae) from the Iberian Peninsula. - Bot. J. Linn. Soc. 125: 319-329. https://doi. org/10.1006/bojl.1997.0117

Boğa, M., Yilmaz, P. K., Cebe, D. B., Fatima, M., Siddiqui, B. S. and Kolak, U. (2014): Chemical constituents and biological activities of Cirsium leucopsis, C. sipyleum, and C. eriophorum. - Z. Naturforsch. 69: 381-390. https://doi.org/10.5560/znc.2014-0071

Bruhl, J. J. and Quinn, C. J. (1990): Cypsela anatomy in the 'Cotuleae' (Asteraceae-Anthemideae). - Bot. J. Linn. Soc. 102: 37-59. https://doi.org/10.1111/j.1095-8339.1990. tb01868.x

Charadze, A. L. (1998): Cirsium Mill. emend. Scop. - In: Bobrov, E. G. and Cherepanov, S. K. (eds): Flora of the USSR, vol. 28. Bishen Singh Mahendra Pal Singh and Koeltz Scientic Books, pp. 52-214.

Cron, G. V., Robbertse, P. J. and Vincent, P. L. D. (1993): The anatomy of the cypselae of species of Cineraria L. (Asteraceae-Senecioneae) and its taxonomic significance. Bot. J. Linn. Soc. 112: 319-334. https://doi.org/10.1111/j.1095-8339.1993.tb00323.x

Davis, P. H. and Parris, B. S. (1975): Cirsium Miller. - In: Davis, P. H. (ed.): Flora of Turkey and the East Aegean Islands, vol. 5. Edinburgh University Press, Edinburgh, pp. 370-411.

Dittrich, M. (1977): Cynareae - systematic review. - In: Heywood, V. H. et al. (eds): The biology and chemistry of the Compositae. Vol. 2, London, pp. 999-1015.

Dittrich, M. (1985): Morphologische und anatomische Untersuchungen an Blüten und Früchten der Gattung Carlina (Compositae). Teil I. - Bot. Jahrb. Syst. 107: 591-609.

Duman, H., Tugay, O., Dirmenci, T. and Ertuğrul, K. (2017): A new species of Cirsium sect. Epitrachys (Asteraceae: Cardueae) from the south of Turkey. - Turk. J. Bot. 41: 375-382. https://doi.org/10.3906/bot-1612-33

Frangiote-Pallone, S. and de Souza, L. A. (2014): Pappus and cypsela ontogeny in Asteraceae: structural considerations of the tribal category. - Rev. Mex. Biodivers. 85: 62-77. https://doi.org/10.7550/rmb.32809

Fritz, E. and Saukel, J. (2011): Secretory structures of subterranean organs of some species of the Cardueae, and their diagnostic value. - Acta Biol. Cracov., Ser. Bot. 53(1): 63-73. https://doi.org/10.2478/v10182-011-0009-0

Garg, S. K. and Sharma, K. C. (2007): Taxonomical significance of the micromorphological and scanning electron microscopic surface patterns of cypselas in some mem- 
bers of the tribe Heliantheae (Asteraceae). - Feddes Repert. 118: 165-191. https://doi. org/10.1002/fedr.200711134

Geng, S. L., An, Z. X. and Tian, Y. W. (1994): The studies of fruit anatomy and systematic classification of tribe Senecioneae in Xinjiang. - J. Aug. 1st Agr. Collect. 17: 9-17.

Grau, J. and Hopf, H. (1985): Das Endosperm der Compositae. - Bot. Jahrb. Syst. 107: 251268.

Häffner, E. (2000): On the phylogeny of the subtribe Carduinae (tribe Cardueae, Compositae). - Englera 21: 1-206. https://doi.org/10.2307/3776757

Inceer, H., Kalmuk, N. A., Imamoglu, K. V., Arslan, G., Duman, O., Hayırlıoglu-Ayaz, S. and Guner, G. (2018): Achene anatomy and stomatal characteristics of eighteen Crepis L. (Asteraceae) taxa from Turkey with notes on their systematic significance. - Nordic J. Bot. 36: e01829. https://doi.org/10.1111/njb.01829

Inceer, H., Bal, M., Ceter, T. and Pinar, M. (2012): Fruit structure of 12 Turkish endemic Tripleurospermum Sch.Bip. (Asteraceae) taxa and its taxonomic implications. - Plant Syst. Evol. 298: 845-855. https://doi.org/10.1007/s00606-012-0596-6

Kadereit, J. W. and Jeffrey, C. (2007): Flowering plants. Eudicots: Asterales. - In: Kubitzki, K. (ed.): The families and genera of vascular plants, Vol. 8. Springer, Berlin, pp. 60-64.

Köstekci, S. and Arabaci, T. (2011): Cypsela morphology of Cirsium sect. Cirsium (Asteraceae) taxa in Turkey. - Biologia 66: 988-995. https://doi.org/10.2478/s11756-011-0110-6

Lavialle, P. (1912): Recherches sur le développement de l'ovaire en fruit chez les Composées. - Ann. Sci. Nat. Bot. 9: 39-149.

Marzinek, J., De-Paula, O. C. and Oliveira, D. M. T. (2008): Cypsela or achene? Refining terminology by considering anatomical and historical factors. - Rev. Bras. Bot. 82: 549-553. https://doi.org/10.1590/s0100-84042008000300018

Mukherjee, S. K. (2001): Cypselar features in nineteen taxa of the tribe Senecioneae (Asteraceae) their taxonomic significance. - J. Econ. Tax. Bot., Addit. Ser. 19: 253-274.

Ozcan, M. (2016): Systematical investigations on Cirsium aggregatum Ledeb. (Asteraceae, Cardueae) from Turkey. - AKU J. Sci. Eng. 16: 198-204. https://doi.org/10.5578/fmbd.28127

Ozcan, M. (2017): Cypsela micromorphology and anatomy in Cirsium sect. Epitrachys (Asteraceae, Carduoideae) and its taxonomic implications. - Nordic J. Bot. 35: 653668. https://doi.org/10.1111/njb.01670

Ozcan, M. and Akinci, N. (2019): Micromorpho-anatomical fruit characteristics and pappus features of representative Cardueae (Asteraceae) taxa: Their systematic significance. - Flora 256: 16-35. https://doi.org/10.1016/j.flora.2019.04.009

Ozcan, M., Demiralay, M. and Kahriman, A. (2015): Leaf anatomical notes on Cirsium Miller (Asteraceae, Carduoideae) from Turkey. - Plant Syst. Evol. 301: 1995-2012. https:// doi.org/10.1007/s00606-015-1209-y

Ozcan, M., Hayırlıglu-Ayaz, S. and Inceer, H. (2008): Chromosome counts of some Cirsium (Asteraceae, Cardueae) taxa from Turkey. - Caryologia 61: 375-382. https://doi. org/10.1080/00087114.2008.10589649

Ozcan, M., Hayırlıglu-Ayaz, S. and Inceer, H. (2011): Chromosome reports in some Cirsium (Asteraceae, Cardueae) taxa from north-east Anatolia. - Caryologia 64: 55-66. https://doi.org/10.1080/00087114.2011.10589764

Ozcan, M., Ayaz, F. A., Ozogul, Y., Glew, R. and Ozogul, F. (2016): Fatty acid composition in achenes of Cirsium taxa (Asteraceae, Carduoideae) from Turkey. - Z. Naturforsch. 71: 45-54. https://doi.org/10.1515/znc-2015-0128 
Pandey, A. K. and Kumari, A. (2007): Anatomical patterns of pericarp in Asteraceae. - In: Chauhan, S. V. S., Rana, A. and Chauhan, S. (eds): Plant reproductive biology and biotechnology. Aavishkar Publisher, Jaipur, pp. 64-77.

Sears, P. (1922): Variations in cytology and gross morphology of Taraxacum II. Senescence, rejuvenescence, and leaf variation in Taraxacum. - Bot. Gaz. 73: 425-446. https://doi. org $/ 10.1086 / 333034$

Shabestari, E. S. B., Attar, F., Riahi, H. and Sheidai, M. (2013): Seed morphology of the Centaurea species (Asteraceae) in Iran. - Phytol. Balcan. 19: 209-214.

Sheikh Akbari, R. and Azizian, D. (2006): Seed morphology and seed coat sculpturing of Epilobium L. species (Onagraceae Juss.) from Iran. - Turk. J. Bot. 30: 435-440.

Singh, R. P. and Pandey, A. K. (1984): Development and structure of seeds and fruits in Compositae-Cynareae. - Phytomorphology 34: 1-10.

Smith, J. P. (1977): Vascular plant families. - Mad River Press Inc., Eureka, CA, 320 pp.

Spjut, R. W. (1994): A systematic treatment of fruit types. - NYBG Press 70: 1-182.

Stebbins, G. L. (1953): A new classification of the tribe Cichorieae, family Compositae. Madroño 12: 65-81.

Stevens, P. F. (2001): Angiosperm Phylogeny Website, Version 12, (and more or less continuously updated since). - http:// www./mobot.org/Mobot/research/Apweb/. Assessed 07 July 2017.

Uysal, I., Celik, S. and Menemen, Y. (2005): Morphology, anatomy, ecology, pollen and achene features of Centaurea polyclada DC. (Sect. Acrolophus) in Turkey. - Int. J. Biol. Sci. 5: 176-180. https://doi.org/10.3923/jbs.2005.176.180

Yıldız, B. (2012): Cirsium Mill. - In: Güner, A., Aslan, S., Ekim, T., Vural, M. and Babaç, M. T. (eds): Türkiye Bitkileri Listesi (Damarlı Bitkiler). İstanbul: Nezahat Gökyiğit Botanik Bahçesi ve Flora Araştırmaları Derneği yayınları, pp 141-146.

Y1ld1z, B., Arabac1, T. and Dirmenci, T. (2013): Two new species of Cirsium (Asteraceae) and notes on allies from Turkey. - Turk. J. Bot. 37: 1045-1054. https://doi.org/10.3906/ bot-1301-4

Yüksel, E., Kıran, Y., Şahin, A., Yıldız, B. and Arabacı, T. (2013): Karyological studies of 10 Cirsium sect. Epitrachys (Asteraceae) species from Turkey. - Turk. J. Bot. 37: 10851092. https://doi.org/10.3906/bot-1302-1

Zarembo, E. V. and Boyko, E. V. (2008): Carpology of some East Asian Cardueae (Asteraceae). - An. J. Bot. Madrid 65: 129-134. https://doi.org/10.3989/ajbm.2008.v65.i1.250

Zhu, S. X, Qin, H. N. and Shih, C. (2006): Achene wall anatomy and surface sculpturing of Lactuca L. and related genera (Compositae: Lactuceae) with notes on their systematic significance. - J. Integr. Plant Biol. 48(4): 390-399. https://doi.org/10.1111/j.17447909.2006.00245.x

Zomlefer, W. (1994): Guide to flowering plant families. - University of North Carolina Press, Chapel Hill, NC, 424 pp. 
